\title{
Artelogie
}

artelogie Recherche sur les arts, le patrimoine et la littérature de l'Amérique latine

14 | 2019

Sensibilités : Arts, littératures et patrimoine en Amérique latine

\section{Os "meninos índios" que Spix e Martius levaram a Munique}

\section{Maria de Fátima Costa}

\section{(2) OpenEdition \\ 1 Journals}

Edição electrónica

URL: http://journals.openedition.org/artelogie/3774

DOI: 10.4000/artelogie.3774

ISSN: 2115-6395

Editora

Association ESCAL

Refêrencia eletrónica

Maria de Fátima Costa, "Os "meninos índios" que Spix e Martius levaram a Munique », Artelogie [Online], 14 | 2019, posto online no dia 07 janeiro 2019, consultado o 17 setembro 2019. URL : http:// journals.openedition.org/artelogie/3774 ; DOI : 10.4000/artelogie.3774

Este documento foi criado de forma automática no dia 17 Setembro 2019.

Association ESCAL 


\title{
Os "meninos índios" que Spix e Martius levaram a Munique
}

\author{
Maria de Fátima Costa
}

1 Era 1862 quando o naturalista Carl Friedrich Philipp von Martius (1794 - 1868), então com mais de 60 anos, escreveu essas palavras. Com elas recordava-se do momento em que adquiriu um jovem índio da nação Juri durante sua passagem pela Amazônia. A nota faz parte dos registros autobiográficos que o cientista levou ao papel ao final de sua vida, descrevendo acontecimentos que continuavam retidos na sua memória. $O$ tom que adota é nitidamente de exculpação, e delata uma questão que parece ter lhe atormentado durante toda a vida. Na velhice, então, procurando organizar e dar sentido às sensações passadas, projeta uma versão final, tal como gostaria que esse incômodo episódio ficasse perpetuado.

2 O já velho botânico refere-se a uma passagem ocorrida em 1820, durante a viagem científica que, na companhia do zoólogo Johann Baptist von Spix (1781 - 1826), realizou ao Brasil. Os dois naturalistas haviam chegado ao Rio de Janeiro em 1817, como parte da expedição científica austro-bávara organizada por ocasião do casamento da princesa Leopoldina, arquiduquesa de Áustria, com o príncipe herdeiro do império português D. Pedro. Porém, por motivos que não cabem no limite deste artigo, logo se separaram dos colegas austríacos e juntos, Spix e Martius - enquanto acadêmicos da Real Academia das Ciências da Baviera -, conformaram a primeira expedição científica que aquele reino enviou à América.

3 Durante três anos, seja sobre lombo de mulas, seja dentro de canoas, esses dois expedicionários - sempre com o apoio da população e do saber local - percorreram parte significativa do território brasileiro, quando este ainda fazia parte do Reino Unido de Portugal, Brasil e Algarves. Ao todo, Spix e Martius trilharam mais de $14.000 \mathrm{~km}$, tendo visitado as então capitanias do Rio de Janeiro, São Paulo, Minas Gerais, Bahia, Piauí, Maranhão e Grão-Pará - uma grande viagem que foi concluída em agosto de 1820, quando embarcaram no porto de Belém do Pará rumo à Europa (DIENER e COSTA, 2018).

4 Como resultado, essa grande empreitada científica reuniu muitas centenas de espécimes dos três reinos da natureza, produziu vintenas de desenhos registrando vistas de 
paisagens e tipos humanos, recolheu objetos da cultura material de vários povos e nações indígenas com as quais os acadêmicos mantiveram contato, formando, de fato, um grande acervo sobre o Brasil, hoje preservado em diversas instituições muniquenses.

Parte desse acervo foi enviado à Baviera ainda no decorrer da viagem, porém, outra parte, bastante significativa, foi levada pelos próprios Spix e Martius em sua viagem de volta. Nela estavam os diamantes conseguidos em Minas Gerais, os diários de campo, os animais e as plantas considerados mais raros e, claro, todo o material recolhido no trajeto amazônico. Nesse conjunto destacavam-se as coleções de peças vivas, vale dizer, plantas, animais e quatros índios: três Miranha e o jovem Juri. Destes, entretanto, apenas dois conseguiram chegar à Europa: uma mocinha que receberá o nome de Isabela Miranha e o rapaz, referido no trecho autobiográfico de Martius - usado aqui como epígrafe -, que passou a responder pelo nome de Johannes Juri. Neste artigo vamos tratar exatamente desses dois índios, de Johannes e de Isabela, personagens que ficaram conhecidos como os meninos índios que Spix e Martius levaram a Munique.

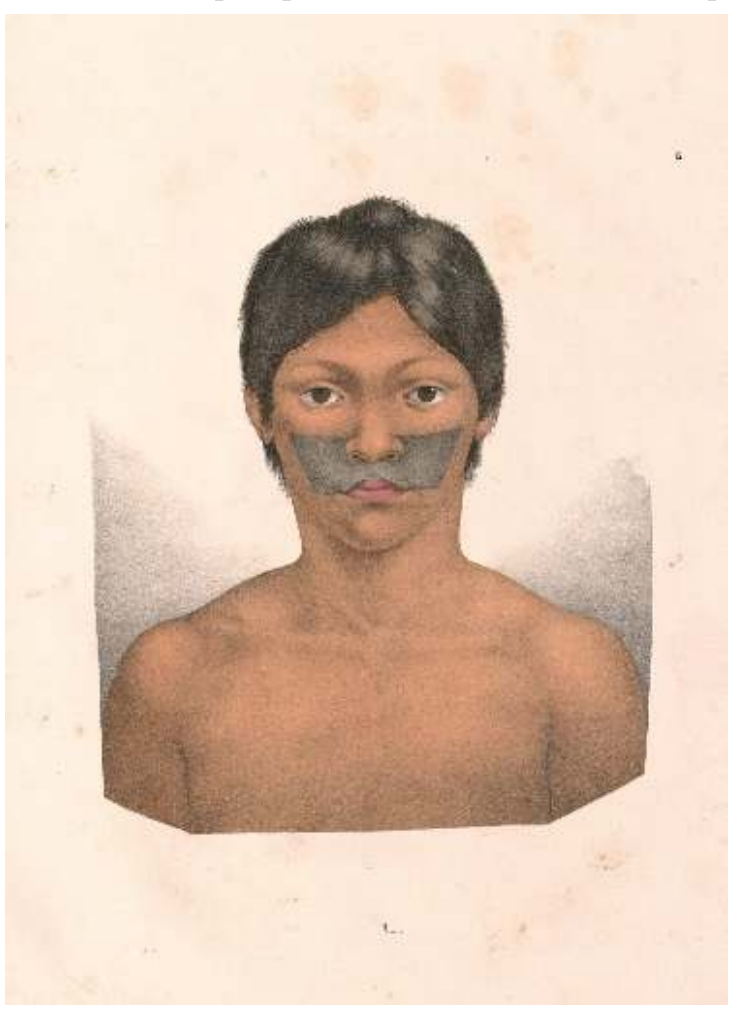

Juri, 1823

P. LUTZ (desenhista [?]; sem identificação do gravador)

Litogravura; $67 \times 45 \mathrm{~cm}$

Fonte: Spix e Martius, 1823-1831.

Reise in Brasilien, vol. IV, Atlas, prancha 15 


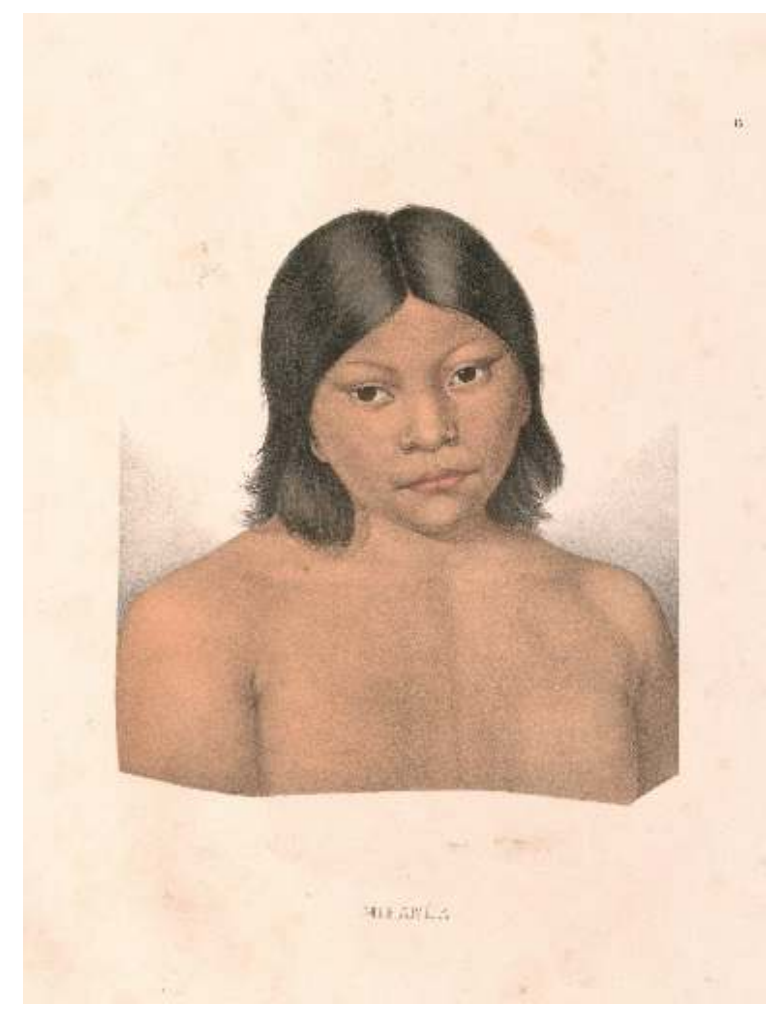

Miranha (Isabela), 1823

P. LUTZ (desenhista [?]; sem identificação do gravador)

Litogravura; 67 × $45 \mathrm{~cm}$

Fonte: Spix e Martius, 1823-1831.

Reise in Brasilien, vol. IV, Atlas, prancha 16

\section{Relação entre índios e viajantes}

Como toda expedição científica que se dirigiu aos territórios americanos, também a caravana bávara tinha dentre os seus focos de interesse - além dos três reinos da natureza - conhecer e estudar as populações humanas que ali viviam. Havia, então, muita curiosidade sobre esses povos sempre tidos como selvagens. Como seria sua constituição física? Quais as características de sua cultura? Que capacidade cognitiva tinham? Enfim, questões várias que poderiam ser respondidas pelo contato direto proporcionado por uma viagem.

7 Ao chegarem à América Portuguesa, Spix e Martius pouco ou quase nada conheciam sobre os povos americanos. Esses acadêmicos, como cientistas educados nas luzes do Iluminismo, conheciam o homem americano a partir dos filtros oferecidos pelas teorias de Carl von Linné e do conde de Buffon. Mas, como alemães, seus olhares estavam guiados mais diretamente pelas formulações dadas por Johann Friedrich Blumenbach (1752-1840) e, principalmente, por Immanuel Kant (1724-1804), através das quais se reafirmava uma pretensa superioridade dos europeus frente a outros povos qualificados de selvagens, como o homem americano. Essa questão torna-se visível nas páginas da narrativa que Spix e Martius publicaram entre 1823-1831 com o título de Reise in Brasilien (Viagem pelo Brasil), na qual descrevem os resultados de sua viagem. 
8 Nessa obra os dois acadêmicos afirmam, por exemplo, que diversos autores judiciosos observaram que algumas raças, embora igualmente organizadas, são, entretanto, qualificadas de mais ou menos perfeitas em diferentes aspectos e, concretamente, no europeu uma constituição superior dos órgãos e forças intelectuais compensariam um menor desenvolvimento das faculdades inferiores. Segundo eles, isso se manifesta de tal modo que bastaria um simples olhar ou a simples presença do branco para amedrontar e intimidar os índios, e os da raça etiópica (os negros) e os mestiços de ambas (SPIX e MARTIUS, 1938, tomo I, p. 243).

9 Para os dois bávaros, o europeu pertencia, pois, a uma raça superior, aristocrata da humanidade. Já o americano era tido como um ser inferior, um selvagem. Nesse sentido, caberia aos europeus, incitados por nobres sentimentos, espalhar a civilização cristã e científica às terras mais remotas (ibidem, p. 72).

10 Mas, uma vez no Rio de Janeiro, quase não veem indígenas, pois, segundo os viajantes, muito raramente os índios, tal aves de arribação, aparecem na cidade. Apesar disso, o primeiro contato que os acadêmicos bávaros mantiveram com um indígena ocorreu nessa cidade, ainda no ano da sua chegada. Isso se passou quando visitaram a casa do naturalista alemão barão G. H. von Langsdorff (1774 - 1852), que à época exercia o cargo de Cônsul Geral de Todas as Rússias na corte de D. João VI. Ali, no âmbito da vida privada, foi que Spix e Martius encontraram um botocudo que servia domesticamente a Langsdorff. A história da forma que esse personagem chegou ao barão oferece uma imagem bastante significativa de como os índios eram vistos pelos europeus. E vale abrir um hiato para contá-la.

11 Tudo começou com o pedido de um crânio de um botocudo que Antônio de Araújo e Azevedo, o conde da Barca - então ministro na corte de D. João VI -, teria feito ao comandante do distrito dos índios Guido Tomás Marlière. La Barca pretendia enviar esse crânio a Gotinga - Alemanha, como presente para o professor Blumenbach. Porém, como Marlière não encontrou nenhum crânio disponível, decidiu mandar ao Rio de Janeiro dois botocudos vivos, que os seus soldados haviam prendido de surpresa. Ocorre que nesse interim Araújo Azevedo faleceu e os índios foram parar com Langsdorff, que ficou apenas com um deles, do outro nada sabemos. Esse botocudo passou então a servir o cônsul não somente como peça viva de gabinete, porém, igualmente, como coletor de curiosidades naturais (ibidem, p. 95, grifo da autora).

12 Chama atenção o termo peça viva de gabinete usada por Spix e Martius para se referirem ao botocudo, deixando evidente que Langsdorff exibia o índio aos seus convidados como um objeto a mais do seu gabinete de curiosidades, fato que parece ter marcado indelevelmente os dois bávaros. Porém, não sabemos se foi essa experiência que levou os dois viajantes a também quererem adquirir um índio para ser peça viva de suas coleções, ou se antes de visitar a casa de Langsdorff já namoravam essa ideia. Certo é que logo os acadêmicos trataram de conseguir um índio para, na volta, levarem consigo a Munique.

13 A primeira oportunidade para isso surgiu quando Spix e Martius passaram por Minas Gerais, exatamente quando visitaram a Fazenda Guidoval, vale dizer, o distrito dos índios comandados por Guido Marlière. Ali tiveram por alguns dias convívio com Puri e Coroado, ocasião na qual reuniram ricas informações e peças etnográficas desses povos. Além disso, à saída, receberam dois Coroado, episódio que os naturalistas descreveram com certa ironia nas páginas do Viagem pelo Brasil: Na véspera da partida, à tarde, trouxeram dois jovens Coroados à nossa casa, e os animaram a seguir conosco, com a promessa de cachaça e de voltarem como capitães, com vistosas fardas. Dava vontade de rir ao ver o feito que um uniforme reluzente 
produz nesses homens das selvas. Vestiram com ela um dos índios, lhe puseram-lhe à cabeça o chapéu armado, e colocaram diante dele um espelho. Orgulhoso e perplexo pasmava, mirando-se a si mesmo por todos os lados e à sua figura no espelho, e apalpava ora o novo fato, ora o espelho; embora não pudesse compreender o feitiço, contudo, predominava nele, sem dúvida alguma, o sentimento de vaidade satisfeita. Desse momento em diante, estava tomada a resolução, e ele mostrava o prazer de acompanhar-nos (ibidem, p. 359).

Um deles, porém, fugiu logo à saída da Fazenda Guidoval; o outro, a quem os expedicionários deram o emblemático nome de Custódio, entretanto, permaneceu na caravana. Mas, para desapontamento dos bávaros, passados oito meses, Custódio também deixou a expedição quando essa visitava aldeias Kamakã no sul da Bahia - sua fisionomia está registrada nas páginas do Atlas que acompanhou os três tomos do Viagem pelo Brasil, sendo mostrada como o retrato de um Coroado.

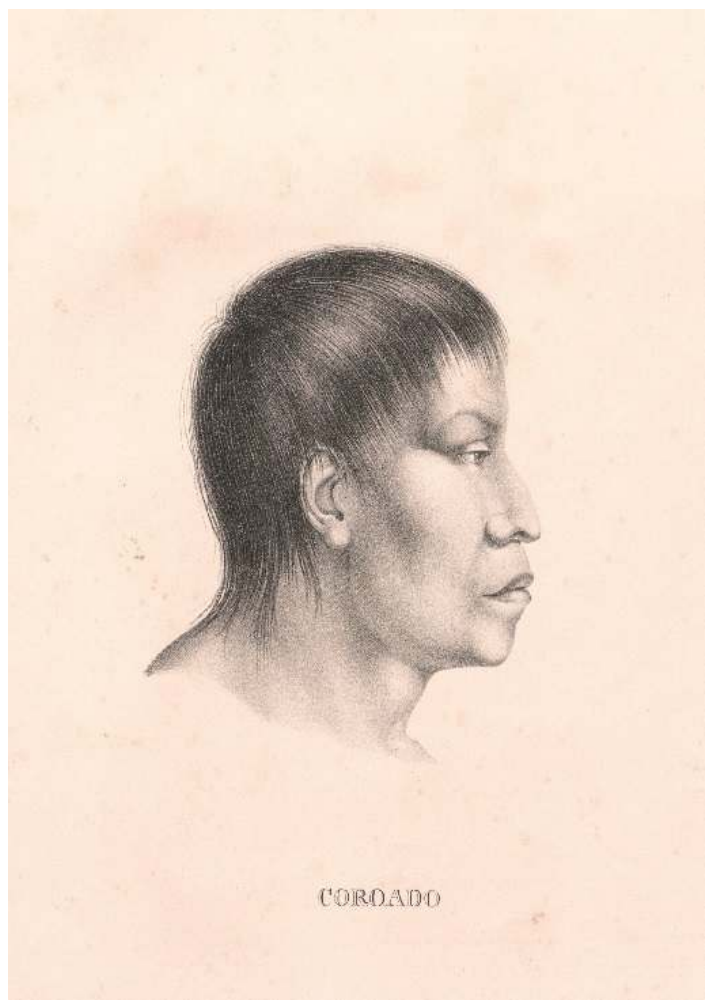

Coroado (Custódio), 1823

J. B. von SPIX ou C. F. PH. von MARTIUS

(desenhista; sem identificação do gravador)

Litogravura; $47 \times 65 \mathrm{~cm}$

Fonte: Spix e Martius, 1823-1831.

Reise in Brasilien, vol. IV, Atlas, prancha 5 (Detalhe)

Depois desse episódio, talvez temendo novas fugas, os dois acadêmicos só voltaram a recolher outras peças vivas no final da viagem, quando visitaram a Amazônia.

Vale observar que, nos séculos XVIII e XIX, levar indivíduos da população local no retorno da viagem à Europa era um procedimento comum entre aqueles que realizavam expedições científicas de caráter naturalista. São bastante conhecidas, por exemplo, as glamorosas histórias do taitiano Omai, que o capitão James Cook levou a Londres ao término da sua segunda viagem de circum-navegação. Esse hábito também foi recorrente dentre aqueles que visitaram as terras brasileiras no século XIX. Sabemos, entre outros, 
do jovem botocudo de nome Huêk, que o príncipe Maximiliano de Wied-Neuwied, que esteve no Brasil entre 1815 - 1817, levou consigo no seu retorno, e de um rapaz Apinajé chamado de Katana, que Francis de Castelnau, por sua vez, levou à França. Surpreende, contudo, que Spix e Martius, ao embarcarem no Pará, tenham levado não um, mas quatro índios, entre meninos e meninas.

\section{Entrada de Miranha e Juri na expedição}

A maneira como esses quatro índios passaram a integrar a caravana bávara é uma questão ainda um tanto nebulosa, uma vez que os próprios expedicionários criaram diferentes versões sobre a aquisição dos jovens Miranha e Juri. Para os Miranha conhecemos três diferentes narrativas.

18 A primeira foi dada por Spix e Martius no Relatório que enviaram de Lisboa ao rei Maximiliano José I da Baviera, no qual informaram da última etapa da viagem. De acordo com esse informe ao rei, os índios dessa etnia teriam sido recolhidos por Martius durante a visita que o acadêmico realizou à localidade denominada Porto dos Miranhas, na Amazônia. Na ocasião, o botânico estava na companhia do comerciante italiano Francisco Ricardo Zany, enquanto Spix realizava outro trajeto, em separado. Zany costumava ir àquele porto com o fim de adquirir índios do tuxana miranha, que atendia pelo nome português de João Manuel. Para tanto, esse chefe promovia guerras contra outras etnias e também contra grupos dos próprios Miranha, e os vencidos eram transformados em mercadoria. Segundo consta no mencionado Relatório, quando Martius e Zany chegaram ao Porto dos Miranhas, o tuxana se ofereceu para fazer uma incursão contra os seus inimigos 
com o propósito de capturar índios adultos para o capitão Zany e algumas crianças para nós (SPIX e MARTIUS, 1817-1820, p. 128. Ms. BSB, cod. Cgm 5982; grifo da autora).

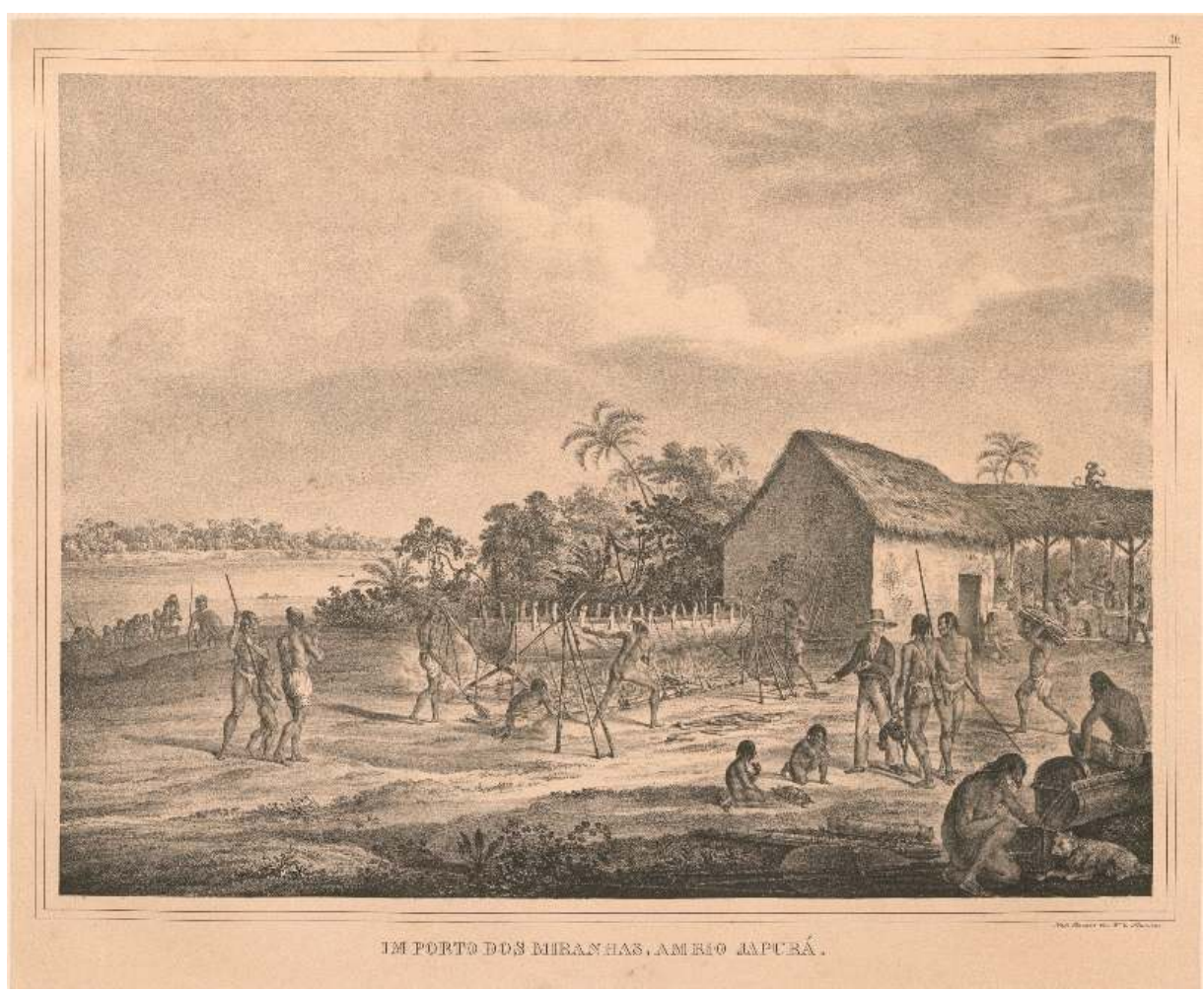

No porto dos Miranhas, no rio Japurá, 1828.

C. F. PH. VON MARTIUS (desenhista), J. SELB (gravador)

Litogravura; 32,8 $\times 44,2 \mathrm{~cm}$

Fonte: Spix e Martius, 1823-1831.

Reise in Brasilien, vol. IV, Atlas, prancha 30

Essas palavras nos fazem ver que, ao chegar àquele porto, Martius estava ciente que o chefe Miranha faria uma incursão militar com o fim de capturar prisioneiros para serem negociados pessoalmente com o capitão Zany e com ele. Porém, no terceiro tomo do Viagem pelo Brasil surge uma segunda versão. Vale observar que esse tomo, embora também traga como autores Spix e Martius, foi escrito unicamente pelo botânico, como ele mesmo esclarece no corpo da narrativa. Nessa versão, Martius conta que foi somente quando deixava aquele porto que ele fez negociações com o chefe João Manuel. Seu interesse, entretanto, teria sido de adquirir apenas objetos da cultura material desses indígenas e exemplares de plantas. Porém, o tuxana lhe ofereceu cinco jovens índios duas moças e três rapazes - em troca de machados e facas. O botânico, então, explica que aceitou os jovens índios das mãos do desumano, com tanto maior empenho, quanto sabia que, ficando aqui, eles teriam morte certa, por já estarem todos atacados da febre (SPIX e MARTIUS, 1938, tomo III, p. 356). Ou seja, segundo essa versão, não teria havido qualquer acerto prévio sobre captura de crianças, e Martius havia ficado com os índios por razões humanitárias.

Por fim, sabemos também, através das páginas da narrativa, que dos cinco que Martius recebeu do tuxana, dois foram deixados no Pará - um na vila de Ega, com o comandante militar, e outro em Belém, com o ouvidor - e três ficaram com os expedicionários (SPIX e MARTIUS, 1831, tomo III, p. 1264-1265). 
do, há ainda uma terceira e muito breve, mas bastante significativa versão sobre esse tema, também de autoria de Martius, escrita pelo botânico no passe-partout de um retrato que ele mandou fazer de Isabela, quando ela já estava em Munique. Não sabemos a data da inscrição, mas nela Martius observa: Isabella da tribo dos Miranha. Recebida do Sr. Man[oel] Joaq[uim] do Paço, governador do Rio Negro. † Munique, outubro 1822 (MARTIUS, s/d. Ms. BSB Martiusiana, cod. I.A.1.7.). Nessa construção, o botânico omite totalmente os acontecimentos do Porto dos Miranhas e procura fazer crer que a menina havia chegado a ele como um presente dado pelo governador do Rio Negro.

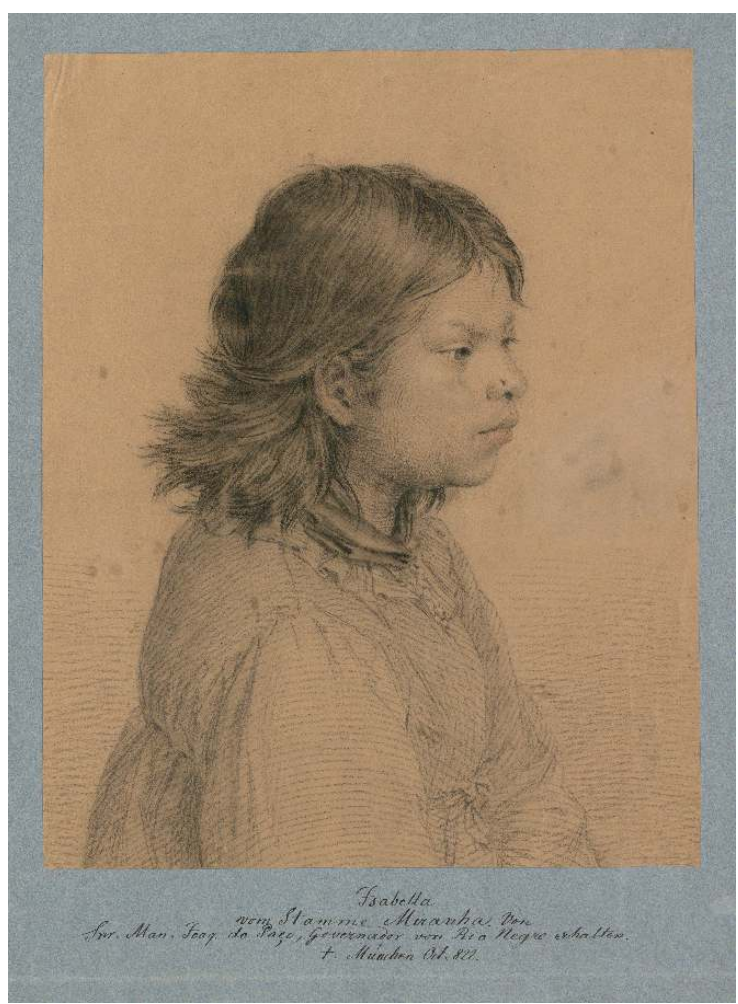

Isabella, 1820-1821.

Sem autor (provavelmente P. LUTZ)

Carvão e lápis sobre papel; 47,6 × 38,4cm

BSB Martiusiana, cod. I.A.1.7. Munique.

Quanto à entrada do jovem Juri na expedição, as informações são mais restritas. Sobre isso não há qualquer referência no Relatório que Spix e Martius enviaram ao rei, e na narrativa Martius informa apenas que esse índio foi incorporado à caravana quando o botânico passou pelas terras de Zany em Alvelos. Em suas palavras: Agregou-se ali à guarnição um jovem juri, da horda comá-tapuia, que nos acompanhou até Munique; infelizmente, tanto ele como a jovem miranha, sua companheira, morreram, mal suportando a mudança de clima e as novas condições exteriores (veja-se no Atlas o retrato do Juri) (SPIX e MARTIUS, 1938, Tomo III, p. 365-366).

De fato, no Atlas aparece tanto o retrato de Juri como o de Isabela, esta identificada como uma Miranha. E, no fundo Martiusiana da Biblioteca do Estado da Baviera, há um desenho do jovem índio, que traz no passe-partout a inscrição Juri da tribo dos Juri-Comas, no rio Pureos, na fazenda Manacaru do Cap[itão]. Ric[ardo]. Franc[isco] Zany, escolhido por mim entre os seus índios, em março de 1820. † Munique, fevereiro 1821 (Ms. BSB Martiusiana, cod. I.A.1.7), versão que é bastante coincidente com a que o botânico publicou na narrativa. Porém, 
como vimos na nota autobiográfica escrita 42 anos depois, Martius omite as circunstâncias em que aquele episódio ocorreu.

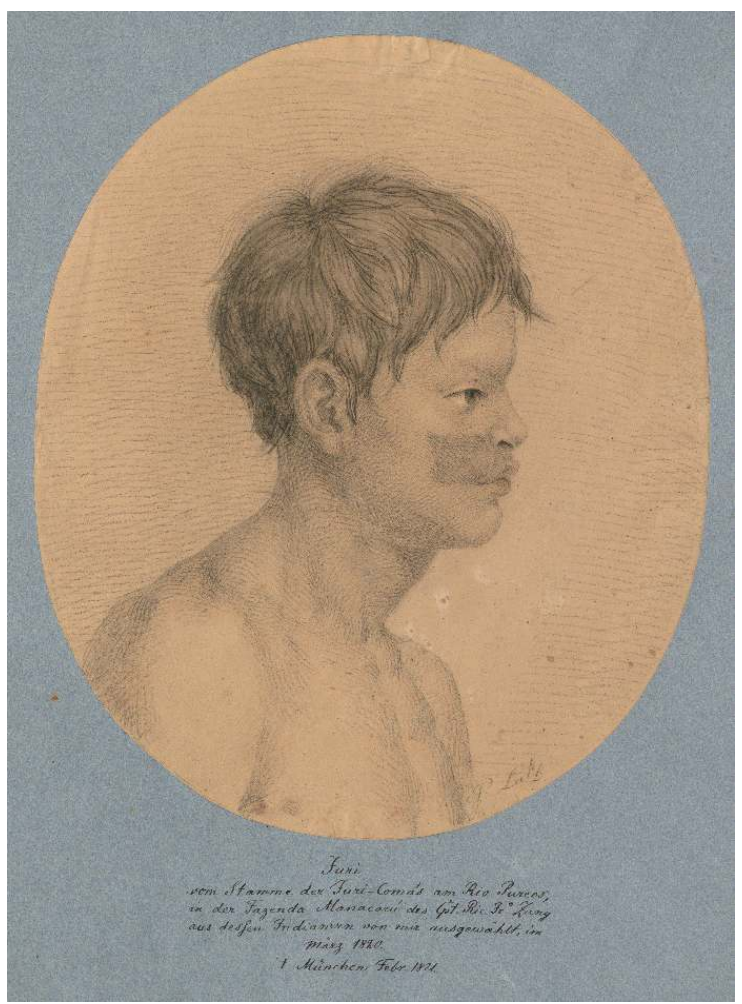

Juri, 1820-1821

P. LUTZ

Carvão e lápis sobre papel;

$46,8 \times 39,3 \mathrm{~cm}$

BSB Martiusiana, cod. I.A.1.7. Munique

24 A existência de todas essas diferentes versões deixa evidente que a entrada desses índios tanto os Miranha como o Juri - na expedição se configura como uma questão, no mínimo, incômoda para Martius, talvez porque todos eles faleceram em pouquíssimo tempo.

\section{Miranha e Juri na Europa}

Era 14 de junho de 1820 quando Spix e Martius embarcaram na galera portuguesa Nova Amazona, rumo a Lisboa. Levaram consigo grandes coleções e quatro índios, com idades presumidas entre 8 e 14 anos. Dois deles, entretanto, não resistiram à viagem transoceânica. Martius debitou essas mortes a atitudes tomadas pelo capitão do navio que, segundo ele, havia posto em prática toda sorte de picardias para lhes dificultar a viagem: prejudicou as coleções, principalmente de plantas e animais vivos, e também os índios, que por falta de assistência foram a óbito por problemas hepáticos (SPIX e MARTIUS, 1938, Tomo III, p. 477).

Ainda era verão quando os dois bávaros e seus índios sobreviventes aportaram na capital lusitana. Lisboa os recebeu em meio às revoltas liberais, que naquele ano haviam eclodido na cidade do Porto. Permaneceram nesta cidade conflagrada apenas o tempo necessário para despachar suas coleções à Baviera e cuidar dos documentos para poderem, eles também, seguir para Munique. Os papéis foram rapidamente conseguidos na embaixada 
austríaca de Lisboa, de maneira que em outubro partiram por terra, através da Europa, passando por Madri, Lyon e Estrasburgo.

27 Os dois naturalistas, com o casal de índios, formavam um grupo bastante peculiar. A comunicação entre eles era, no mínimo, precária e realizada em português, língua que nenhum deles dominava: Spix e Martius a haviam aprendido durante a viagem, Isabela quase nada entendia e Juri, talvez o mais fluente, tinha um vocabulário rudimentar que lhe permitia se comunicar com os expedicionários. Temos de levar em conta, ademais, que Juri e Miranha provinham de nações indígenas distintas, falavam línguas diferentes, cada um tinha memórias ancestrais próprias do seu povo e, o mais importante, eram inimigos étnicos.

O certo é que, apesar de suas diferenças, tiveram de dividir o pequeno espaço das carruagens e hospedarias durante os dois meses que durou a travessia terrestre entre Lisboa e Munique. Porém, ainda não conseguimos saber detalhes dessa viagem. Como teria sido o dia a dia? Onde paravam, como dormiam, o que comiam? São questões em aberto, mas podemos deduzir, sim, que essa convivência não deve ter sido fácil, principalmente para os dois adolescentes, que tinham diante de si uma cultura totalmente distinta das suas e eram, com toda certeza, objeto da curiosidade geral, afinal peças vivas de um mundo distante. Além disso, deslocavam-se numa região em que, a cada dia, a temperatura se tornava mais fria.

29 De qualquer maneira, remediando essas barreiras culturais, o grupo finalmente chegou à capital da Baviera. Era 8 de dezembro de 1820, ano em que o inverno foi dos mais rigorosos. Todos chegaram muito debilitados. A cidade, entretanto, os recebeu calorosamente. Para Spix e Martius era o coroamento de um feito. Todos os jornais renderam loas a essa chegada; eram os heróis que retornavam à casa e ainda traziam dois índios, figuras que rapidamente se tornaram o centro da curiosidade geral.

\section{Os meninos índios em Munique}

Logo ao chegarem, Spix e Martius, junto com Isabela e Juri, passaram a noite na hospedaria Goldener Hahn, mas já na manhã do dia seguinte tiveram a honra de ser recebidos em audiência por Suas Reais Majestades (Flora, 12.12.1820). Foi nesta ocasião que os meninos índios foram apresentados à corte de Maximiliano José I. Nessa mesma cerimônia, o rei concedeu aos dois cientistas o título de Cavaleiro da Ordem ao Mérito da Coroa da Baviera, permitindo que ambos acrescentassem a partícula von aos seus nomes e ainda os convidou para, junto com os índios, irem residir numa das alas do Palácio Real. E assim o fizeram.

31 Esses fatos logo chegaram a toda a sociedade muniquense pelas páginas dos periódicos Flora - Ein unterhaltungs Blatt [Uma revista para o entretenimento] e Müncher Politische Zeitung [Jornal Político de Munique], que circularam no dia 12 de dezembro de 1820, nas quais também informavam sobre os dois índios: O Flora noticiava que são um rapaz e uma menina de uns 12-14 anos. O rapaz tem boa estatura e a fisionomia do rosto é do tipo que também poderíamos encontrar entre nós, nos estratos mais baixos da sociedade. Em torno da boca tem um quadrado tatuado, mas que não apresenta incisões, como às vezes se vê entre os mouros [...]. O seu cabelo é preto, duro e liso, como também o da menina. A sua cor é amarelo-marrom. A menina é baixinha, de figura larga e sem qualquer expressão no rosto. Dizem que provém de uma horda de 
antropófagos. 0 rapaz, porém, vem das proximidades dos assentamentos portugueses no Brasil, por isto quiçá a sua fisionomia [seja] mais nobre (Flora, 12.12. 1820).

E, segundo a Münchner Politische Zeitung [Jornal Político de Munique], depois da noite passada na hospedaria Goldener Hahn, os dois viajantes estão hospedados nas dependências do Palácio, onde também estão os dois jovens índios, aos quais, por cortesia dos Srs. Spix e Martius, até agora tinha acesso quem quisesse vê-los. [...] No que diz relação com o rapaz, deve ter no máximo 12 anos e é filho de um cacique de uma horda, morto em uma batalha [...]. A menina não tem tão bom aspecto, mais parece uma criança estúpida, que ficou detida no seu desenvolvimento. [...]. Os doutores Spix e Martius trouxeram seis criaturas como essas para a pátria, porém quatro morreram durante a viagem. 0 menino está vestido na forma dos Hussardos bávaros e o cabelo cortado; a menina leva um vestido feminino de cor azul, e tem o cabelo liso que cai reto (Münchner Politische Zeitung, 12.12. 1820, p. 48-49).

Juri e Isabela estavam, sem dúvida, entre as peças mais vistosas das coleções que Spix e Martius entregaram ao rei, e não é difícil imaginar quantos, atraídos por essas notícias, foram até o Palácio Real ver as criaturas que por cortesia de Spix e Martius poderiam receber a visita de quem quisesse vê-los. Os visitantes chegavam, entretanto, com uma ideia préconcebida sobre os dois meninos índios. Tal como os jornais informavam, apesar de trazer uma tatuagem no rosto, Juri possuía uma bela figura e, por ter tido contato com portugueses, uma fisionomia de aspecto nobre, que até poderia ser europeia. Além disso, era filho de um chefe que perdeu a vida numa batalha. Já a menina Miranha era feia: baixinha, larga e de aspecto hostil e, ainda por cima, pertencia a uma horda de antropófagos

Não sabemos de onde o periódico extraiu a notícia de que Juri era órfão e que seu pai havia sido morto em combate, mas, possivelmente, derivou de uma informação dada diretamente pelos viajantes - única fonte disponível - e que foi mal interpretada pelos órgãos de imprensa, sedentos de sensacionalismo.

Trata-se de uma invenção, pois, como Martius escreveu quarenta anos depois em sua nota autobiográfica, quando ele recolheu o jovem Juri seu pai estava presente, e ainda lhe dirigiu um olhar enigmático que marcou indelevelmente o botânico (Martius, 1794-1868. Ms. BSB Martiusiana, cod. III.A.3.4,].

Seja como for, de concreto temos que essas matérias criaram na sociedade bávara uma imagem dual que colocava os jovens em campos opostos. É certo que Juri e Isabela pertenciam a nações distintas, não falavam a mesma língua, eram inimigos étnicos e, certamente, sentiam mútua repulsa. A convivência deveria ser muito difícil. Porém, as notícias só ajudavam a aumentar a distância entre eles, com uma clara denegação de Isabela: se diz que o menino sente a maior rejeição contra a menina, porque ela pertence a uma tribo de selvagens que matou e comeu seu pai (Münchner Politische Zeitung, 22.12. 1820, p. 70; grifo da autora). Já não bastava ser feia, retardada e antropófaga; para a sociedade bávara agora a mocinha Miranha era também responsável indireta pela morte do pai do belo e dócil Juri, que o seu povo havia matado e comido.

E as notícias não paravam. Passado mais de um mês, em final de janeiro, foi a vez de EOS Eine Zeitschrift aus Baiern zur Erheiterung und Belehrung [Uma revista da Baviera para diversão e aprendizado], de Munique, periódico semioficial do governo, também publicar matérias sobre Isabela e Juri. Entretanto, diferente dos demais periódicos, EOS procura passar aspectos do dia a dia e de questões mais pessoais que envolvem a convivência dos índios com os acadêmicos. Por exemplo, na edição de 23 de janeiro de 1821, trata da saúde 
de ambos, explicando que desde a chegada os dois sofreram muito pela influência do clima e de um tempo extraordinariamente hostil, passando um bom período doentes. Primeiramente, Isabela foi atacada por fortes tosses e febres, mas reagiu bem aos medicamentos e cuidados. Quanto à saúde de Juri, EOS informa que imediatamente depois que Isabela melhorou, Juri caiu doente, sofrendo de um mal de peito, que se agravou em tal extremo que fez temer por sua vida. Sofreu grave inflamação, o que levou os médicos a sangrá-lo nove vezes. A maior incidência da febre já passou, mas Juri continua sendo acometido por fortes tosses, acompanhada por febre leve, de maneira que a doença e suas consequências ainda não foram completamente superadas (EOS, 23.01.1821, p. 31).

38 Esse quadro, de acordo com o periódico, levou os médicos a fazerem nada menos que nove sangrias no adolescente. Na primeira vez, inclusive, houve a necessidade de cobrirem sua cabeça até os olhos para que ele não visse o procedimento. Depois, entretanto, Juri conseguiu acompanhar a sangria e passou a questionar o trabalho dos médicos, suspeitando que os europeus o cortavam com a intensão de ir, pouco a pouco, tirando-lhe a vida. Essas dúvidas, segundo EOS, foram afastadas por Spix e Martinus. E, pelo fato de Juri passar a sentir melhoras, logo o seu comportamento se fez calmo e amável, de modo que todos que o acompanharam ficaram gostando dele (ibidem).

Quanto à aparência física, EOS também procurou traçar um retrato desses dois personagens, e nesse aspecto muito se aproxima das descrições precedentes: Isabela era feia de rosto e de corpo, enquanto Juri aparecia como portador de uma bela estrutura corporal, com uma face nada desagradável. Ele possuía um rosto menor que o de Isabela, belos olhos negros e olhar amável. Isabela estava deformada pelas perfurações no seu nariz e Juri pela tatuagem, de largura considerável, ao redor da boca. Além disso: Isabella provém de uma das tribos indígenas mais primitivas; possui muitas habilidades naturais e uma grande perspicácia, porém pouca bondade; muita teimosia e sempre se mostra hostil, razão pela qual com ela se faz necessário um tratamento áspero. Não lhe faltam, porém, vaidades femininas. Juri evidencia que sua tribo esteve com maior contato com os brancos; tem capacidade de raciocínio, muita bondade e boa disposição com o mundo em sua volta; qualidade que Isabella não possui. Sua expressão é aberta e também é mais falante que Isabella (ibidem).

Ademais, o jornal empenha-se em mostrar como o convívio com os acadêmicos estava mudando seus hábitos e informa aos leitores que os dois já começam a adquirir costumes e comportamentos europeus: já estavam gostando de sentar-se à mesa e de dormir em camas. E, o mais importante, os meninos davam sinais de estarem adquirindo alguns sentimentos, que antes thes eram completamente alheios; por exemplo, Isabella, proveniente de uma tribo que vive completamente nua, à exceção de uma faixa que usam nos quadris, recentemente, só com muita dificuldade e esforço foi possivel despi-la para que posasse para o pintor que faria um retrato, para ser incluído entre as figuras de tribos indígenas na publicação da narrativa dos acadêmicos von Spix e von Martius (ibidem, p. 35).

41 Conhecemos esse retrato, na verdade dois retratos de Isabela totalmente despida, de lado e de costas, que se conservam no fundo Martiusiana da Biblioteca do Estado da Baviera. Trata-se de um registro que, diferente do que o jornal informa, não foi incluído dentre as ilustrações do Atlas que complementa os volumes de Viagem ao Brasil e, até onde sabemos, à época não foi mostrado ao público. 


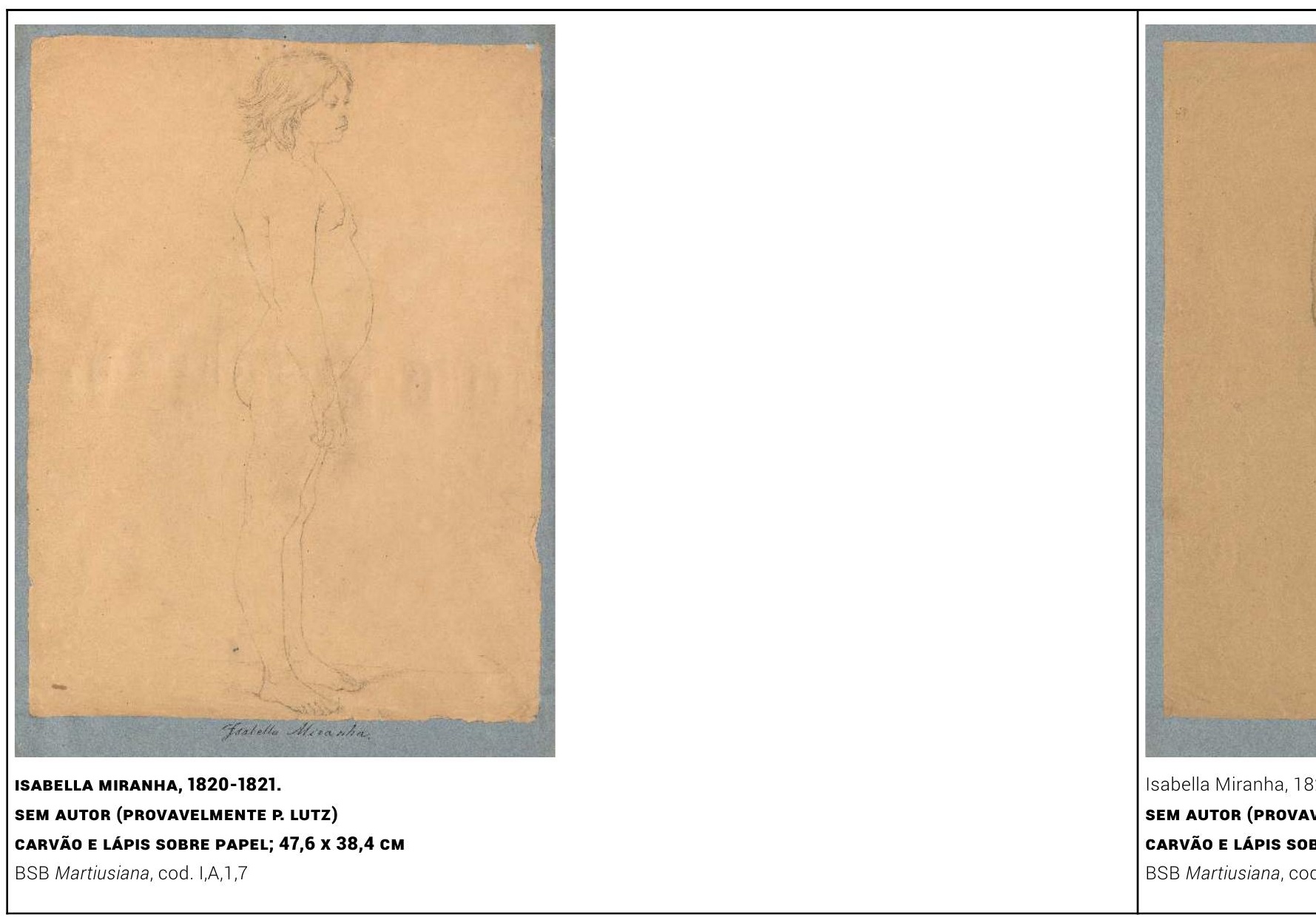

Ao olhá-los realmente se percebe que a mocinha está constrangida, envergonhada. De fato, ela se sentia despida, não porque lhe tiraram as roupas europeias, seu constrangimento era mais profundo; faltava-lhe seu adereço étnico, sem o qual nenhuma Miranha apresentava-se em público: a faixa com que as mulheres do seu povo se vestem. Porém tudo isso era ignorado.

Seus sentimentos, suas emoções e suas memórias ancestrais tornavam-se invisíveis e deveriam ser apagadas, em benefício dos valores que tentavam lhe embutir através de hábitos europeus - agora também contraditórios, obrigando-a a despir-se diante de estranhos. Cabia-lhe entender esses outros códigos.

Sobre isso há uma passagem no diário do filólogo Johann Andreas Schmeller (1785-1852), amigo pessoal de Martius, escrita em 30 de abril de 1821 - portanto, aos quatro meses de estada em Munique -, que nos ajuda a perceber a educação que era dada aos dois jovens: Os meninos Juri e Isabella vieram a dar a mão antes de dormir, para dar as boas noites e para que Spix fizesse o signo da cruz neles, que lhes dissesse também sobre Topana (Deus). Hoje Spix os levou ao santuário Maria Aich. Juri foi de chapéu na cabeça até o altar, provavelmente para escândalo dos presentes na pequena igreja, até que Spix lhe fez um sinal misterioso, que fez intuir o caráter sagrado da casa, e que the indicava para tirar o chapéu (SCHMELLER 1954-1957, p. 429).

Não é à toa, portanto, que Isabela e Juri ficavam seguidamente enfermos. Além do sofrimento físico pelo rigor do clima invernal, temos de levar em conta os aspectos mentais - a violenta pressão psicológica - que exigiam deles grandes esforços de 
aprendizagem para assimilar um universo de valores distintos que, por sua vez, obrigavaos, na mesma proporção, a negar o seu mundo ancestral. Uma batalha hercúlea - e, nessa grande luta, ambos estavam sozinhos. Sim, porque embora fossem vistos como os meninos indios, eram, em realidade, uma Miranha e um Juri em completa solidão. Nesse estado, Isabela e Juri não tinham como sobreviver por muito tempo.

A resistência deles minou, e os pulmões de Juri não suportaram, ele morreu em junho de 1821. Em maio do ano seguinte foi a vez de Isabela, de quem não se registrou a causa imediata do seu falecimento.

Essas mortes, principalmente a de Juri, foram muito sentidas por todos, afinal se perdiam as peças vivas de gabinete, a testemunha viva da viagem. Martius os havia trazido com a presunção de educá-los para a humanidade europeia (MARTIUS, 1794-1868. Ms. BSB Martiusiana, cod. III.A.3.4,). Mas, em verdade, nada conseguiu, além de mortes.

Em homenagem póstuma aos dois, a rainha Karoline da Baviera mandou construir uma bela tumba para abrigar seus restos mortais e contratou o artista Johann Batist Stiglmaier - diretor da Real Academia de Artes - para fazer a estela mortuária.

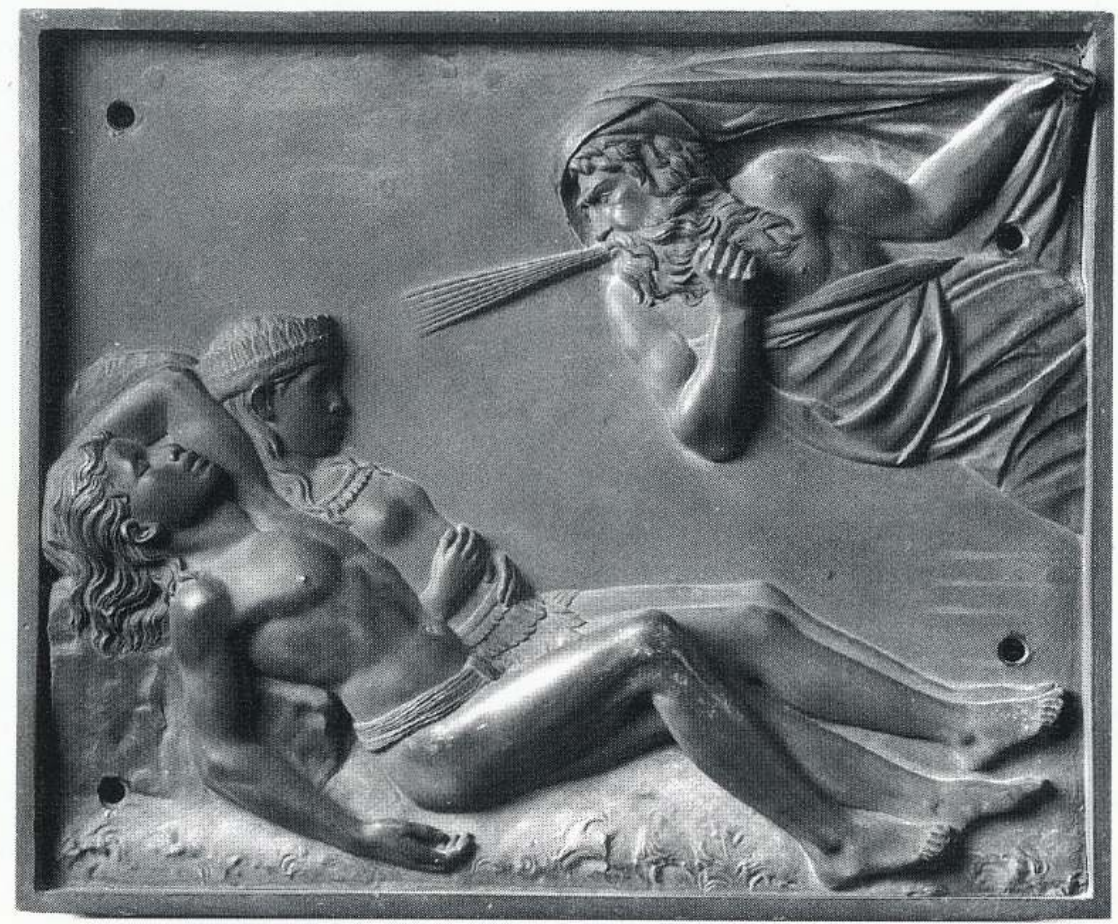

Estela Mortuária da tumba Juri e Isabel, 1822

Johann Baptiste Stiglmaier

Relevo em bronze; 40×48×3

Atualmente no Museu da Cidade de Munique

Fonte: Helbig, J. (Org.), 1994, p. 184.

49 Nela são representados dois jovens que, juntos, parecem estar em estado de sono profundo. 0 rapaz, em primeiro plano, veste apenas uma faixa que contorna seus quadris. A mocinha ao seu lado tem a cabeça ataviada por uma tiara que lembra um cocar, usa um colar e uma pequena saia de plumas. Olhando a representação se constata que nada em suas fisionomias recorda os traços étnicos tão marcados nas descrições veiculadas à sua chegada: a farta cabeleira do menino está muito distante do corte característico de seu 
povo e sua face não traz a tatuagem que lhe dá a identidade de Juri. A menina, por sua vez, nada lembra a figura feia e antropófaga que os jornais muniquenses tanto enfatizaram. Ali está uma bela e delicada adolescente que, de maneira tranquila e harmoniosa, descansa ao lado do seu companheiro. São idealizações que respondem aos desejos civilizatórios dos bávaros com respeito a esses dois jovens. Mostram-se Johannes e Isabela, e não um Juri e uma Miranha. Na decoração do túmulo os bávaros realizaram, finalmente, seu projeto civilizador.

Uma inscrição complementa esse monumento fúnebre, na qual se lê: Furtados da pátria, encontraram cuidados e amor no longínquo lugar do mundo, porém, o implacável e hostil vento do norte os levou. A culpa, pois, é somente do inverno, do frio, enfim, dos elementos da natureza.

Para a sociedade muniquense, os dois meninos morreram por não resistirem aos difíceis fatores climáticos. Essa até poderia ser a causa imediata que pôs fim aos seus sofrimentos físicos, entretanto, para eles a morte foi mais lenta e difícil, e teve início no dia em que os naturalistas lhes tiraram do seu povo.

Foi isso que Martius rapidamente percebeu e do que intimamente se culpou. Tanto assim que, incomodado, mal chegou a Munique, passou a criar versões diversas para explicar como os adquiriu. A primeira já aparece no terceiro volume da narrativa, escrita entre 1829-1830. Ali, como vimos, o botânico distorce o acontecido, mascarando a maneira como adquiriu os índios em Porto dos Miranhas e, em seguida, culpa o capitão do navio português pelas mortes dos dois índios, ocorrida durante a travessia transatlântica. Porém, na velhice a culpa parece ter mais peso, e é assim, usando o tom de exculpação, que o botânico escreve sua nota autobiográfica para contar que nunca conseguiu esquecer o olhar daquele pai, completando: Um ano depois, quando o rapaz morreu em Munique, do mal dos pulmões, isso voltou a mim como uma carga muito pesada. E, então, promove sua autoindulgência: Eu paguei o perigo de ter o endurecimento da alma e com isso aprendi amor e admiração pela natureza humana. Através de uma má ação me transformei num amigo da humanidade (MARTIUS, 1794-1868. Ms. BSB Martiusiana, cod. III.A.3.4,).

\section{BIBLIOGRAFIA}

Manuscritas

SPIX, J. B. e MARTIUS, C. F. Ph. (1817-1820), Relatórios da viagem de Spix e Martius ao Rei Berichte an Seine Majestaet König Max Joseph I von Bayern, erstattet auf der Reise nach Brasilien von den beiden bayr. Akademikern Dr. Spix und Dr. Martius. Ms. BSB, cod. Cgm 5982.

MARTIUS, C. F. Ph. von. (1794-1868) Diversos documentos e escritos autobiográficos, Aufzeichnungen zu verschiedenen Lebensabschnitten. Ms. BSB Martiusiana, cod. III.A.3.4.

Impressas

DIENER, Pablo e COSTA, Maria de Fátima (2018) Martius, Capivara, Rio de Janeiro. 
HELBIG, Jörg (Org.) (1994) Brasilianische Reise 1817-1820. Carl Friedrich Philipp von Martius zum 200. Geburtstag. Catálogo da exposição: Schirn-Kunsthalle Frankfurt (setembro-outubro 1994) e Staatliches Museum für Völkerkunde München (dezembro 1994-abril 1995), Hirmer, Munique.

SPIX, J. B. von e MARTIUS, C. F. Ph. von. $(1823,1828,1831)$ Reise in Brasilien. 3 vols. e 1 Atlas. M. Lindauer (vol. I), I. J. Lentner (vol. II), C. Wolf (vol. III), Munique.

SPIX, J. B. von e MARTIUS, C. F. Ph. von. (1938) Viagem pelo Brasil. 3 vols e 1 Atlas. Trad. de Lucia Furquim Lahmeyer, Imprensa Nacional, Rio de Janeiro.

SCHMELLER, Johann Andreas (1954-1957), Tagebücher. 1801-1852. Editado por Paul Ruf. C.H. Beck, (Schriftenreihe zur bayerischen Landesgeschichte; vols. 47, 48 e 48a), Munique.

Periódicos

EOS - Eine Zeitschrift aus Baiern zur Erheiterung und Belehrung [Uma revista da Baviera para diversão e aprendizado] (02.01.1821), Munique.

EOS - Eine Zeitschrift aus Baiern zur Erheiterung und Belehrung [Uma revista da Baviera para diversão e aprendizado] (23.01.1821), Munique.

Flora - Ein unterhaltungs Blatt [Uma revista para o entretenimento] (12.12.1820), Munique.

Müncher Politische Zeitung [Jornal Político de Munique] (12.12.1820), Munique.

\section{RESUMOS}

Nos séculos XVIII e XIX tornou-se comum que, ao término de suas expedições, viajantes estrangeiros levassem consigo pessoas dos locais visitados, hábito recorrente também entre os que visitaram as terras brasileiras. Neste artigo estuda-se o caso de dois jovens índios da Amazônia que os bávaros J. B. von Spix e C. F. P. von Martius levaram a Munique em 1820: uma jovem Miranha e um rapaz Juri com idade entre 12 e 14 anos. Estes se tornam uma das grandes atrações dentre as peças vivas que os dois naturalistas expuseram em Munique. Porém, Juri faleceu apenas seis meses depois; Miranha, em doze meses. Interessa-nos analisar como se deu a vida desses índios na capital bávara.

Aux XVIIIe et XIXe siècles, il était courant qu'à la fin de leurs expéditions des voyageurs étrangers emmènent avec eux des habitants des lieux qu'ils avaient explorés. Une habitude récurrente chez ceux qui visitaient les terres brésiliennes. Dans cet article, on fait l'étude du cas de deux jeunes Indiens d'Amazonie que les Bavarois J. B. von Spix et C. F. P. von Martius ont ramenés à Munich en 1820 : la jeune Miranha et le jeune Juri, âgés d'environ 12 - 14 ans. Ils constituent l'une des grandes attractions parmi les «pièces vivantes» que les deux naturalistes ont exposées à Munich. Cependant, Juri décède seulement six mois plus tard et Miranha douze mois après. Il s'agit de tenter d'analyser la brève existence de ces Indiens dans la capitale bavaroise.

\section{ÍNDICE}

Palavras-chave: Expedições científicas; viagem ao Brasil; índios da Amazônia; coleções naturalistas; peças vivas.

Mots-clés: Expéditions scientifiques, voyage au Brésil, Indiens d'Amazonie, collections naturalistes, piéces vivantes. 
AUTOR

MARIA DE FÁTIMA COSTA

Universidade Federal de Mato Grosso

mfcosta@ufmt.br 